\title{
КОМПЛЕКСНИЙ АНАЛІЗ ЧИННИКІВ ТА КЛІНІКО-ІНСТРУМЕНТАЛЬНИХ ДАНИХ ПРИ ВІДКРИТІЙ АРТЕРІАЛЬНІЙ ПРОТОЦІ У ДІТЕЙ РІЗНИХ ВІКОВИХ ГРУП
}

\author{
${ }^{1}$ ДУ «Інститут загальної та невідкладної хірургії ім. В. Т. Зайцева НАМН України», м. Харків, Україна \\ ${ }^{2}$ Харківський національний університет імені В. Н. Каразіна, м. Харків, Україна
}

Мета: вивчити і проаналізувати медико-соціальні чинники та клініко-інструментальні дані при відкритій артеріальній протоці у дітей різних вікових груп.

Матеріали і методи. У дослідженні взяли участь діти віком до 18 років, 80 \% з них - діти до 3 років. Усі проходили обстеження у відділенні кардіохірургії дУ «Інститут загальної та невідкладної хірургії ім. В. Т. Зайцева НАМН України» протягом 2013-2017рр. В основну групу увійшли пацієнти з уродженою вадою серця: відкрита артеріальна протока, яку діагностовано за даними комплексного обстеження і даними ультразвуку. Контрольна група - це пацієнти без уроджених вад серця. Виконано статистичний аналіз медико-соціальних чинників, які виявлені при анкетуванні родин, даних об'єктивного огляду, клініко-інструментальних та даних ультразвукового дослідження.

Результати. Встановлено, що серед медико-соціальних чинників найбільш позитивно значущим є планування вагітності, а також скарги на відставання у фрізичному і психомоторному розвитку, часті простудні захворювання та повільна прибавка маси тіла у дітей з відкритою артеріальною протокою у ранньому дитячому віці. Серед непрямих ознак відкритої артеріальної протоки, за даними ультразвукового дослідження, найзначущішими були дилатація лівої гілки і стовбура легеневої артерії та підвищення градієнта тиску на них. Додатковими ультразвуковими критеріями для діагностики відкритої артеріальної протоки слід вважати збільшення передньо-заднього розміру та об'єму лівого передсердя, а також дилатацію лівого передсердя та лівого шлуночка. Зазначені критерії будуть визначними щодо гемодинамічної значущості цієї вади розвитку.

Висновки. Отримані дані дозволяють визначити значущість названих критеріїв у комплексі для вибору подальшої тактики ведення таких пацієнтів, а також стануть невід'ємною частиною алгоритму ведення пацієнтів із відкритою артеріальною протокою.

КЛЮчОВІ СЛОВА: уроджені вади серця; відкрита артеріальна протока; медико-соціальні чинники; додаткові ультразвукові ознаки відкритої артеріальної протоки.

Уроджені вади розвитку (УВР) є лідерами серед причин перинатальної смертності та смертності дітей першого року життя. Вивчення поширеності, структури, причин і чинників ризику зумовлене не тільки відсутністю зниження, а, за деякими даними, й зростанням уродженої патології. Так, за даними ВОO3, число дітей, народжених із уродженими вадами розвитку, в середньому становить 4-6 \%, а в структурі дитячої смертності до $40 \%[2,4]$. Значна кількість робіт, присвячених цьому питанню, формулює УВР як патологію, що включає гетерогенну групу станів із мультифракторіальною етіологією. Автори виділяють кілька груп чинників ризику: соціально-гігієнічні, медикобіологічні та фрактори зовнішнього середовища, серед яких репродуктивний анамнез жінок, забруднення навколишнього середовища, профресійні шкідливості та спосіб життя батьків, рівень їх соматичного здоров'я, приймання лікарських препаратів, вплив інфекційних захворювань та інші $[1,2,4]$.

(с) Д. О. Кулікова, Л. І. Чумак, 2018
Уроджені вади серця (УВС) займають до 30 \% від усіх УВР, поступаючись лише захворюванням опорно-рухового апарату та центральної нервової системи [1].

Відкрита артеріальна протока (ВАП) $є$ такою уродженою вадою, яка спостерігається найчастіше і займає 7-10 \% від загальної кількості всіх УВС [9]. Все частіше в літературі трапляються дані про проблему ВАП у недоношених новонароджених, де широко представлені клінічні критерії діагностики із визначенням їх гемодинамічної значущості. У той же час, як ці аспекти та показання для закриття ВАП у дітей першого року життя і більш старших пацієнтів обговорюють вкрай рідко.

Безперечно, стрес у батьків недоношеної новонародженої дитини з наявністю значущої ВАП із необхідністю оперативного лікування вкрай великий і часто асоційований з виживанням дитини. Однак поява діагнозу «Уроджена вада серця. Відкрита артеріальна протока» у «пренатально здорової дитини» або у дитини старшого віку 
при профрілактичному обстеженні не менш приголомшлива.

Глибокий аналіз різних груп чинників, асоційованих із ВАП, визначення діагностичних критеріїв, включно збір анамнезу, об'єктивний огляд, наявність певного набору клініко-інструментальних даних дозволить визначити прогноз і перспективи таких пацієнтів на різних етапах їхнього життя.

Мета роботи: вивчити і проаналізувати медико-соціальні чинники та клініко-інструментальні дані при відкритій артеріальній протоці у дітей різних вікових груп.

Матеріали і методи. У дослідженні взяли участь пацієнти, діти віком до 18 років, серед яких 80 \% - діти до 3 років. Усі проходили обстеження на базі відділення кардіохірургії ДУ «Інститут загальної та невідкладної хірургії ім. В. Т. Зайцева НАМН України» протягом 2013-2017 рр. Основна група включала пацієнтів із діагнозом «Уроджена вада серця. Відкрита артеріальна протока» 3 верифікованими даними комплексного обстеження та даними ультразвукового дослідження. Контрольна група - це пацієнти без уроджених вад серця.

Першою частиною дослідження є статистичний аналіз чинників ризику, проведений за допомогою анкетування. Другою частиною - об'єктивний огляд і клініко-лабораторні дані без ультразвукового дослідження. Третя і основна частина представлена даними ультразвукового обстеження.

Опитування батьків проводили відповідно до спеціально розробленої анкети («Анамнестична карта для визначення ризику розвитку ВАП у дитини») після отримання добровільної згоди на участь в анкетуванні. В анкету включено питання щодо віку батьків, їх шкідливих звичок, хронічних захворювань, а також дані про характер перебігу вагітності. Всього роздано 460 анкет, а зібрано 432 (відгук 93,9 \%), які були перевірені на правильність і логічність заповнення. У результаті після перевірки для аналізу було відібрано 425 анкет: 218 анкет основної групи і 207 - контрольної. Пацієнти обох груп були обстежені за стандартною схемою, яка включала скарги, огляд, рентгенографрію органів грудної клітки, електрокардіографрію (ЕКГ).

Третьою і основною частиною дослідження був аналіз даних ультразвукового обстеження, проведеного на апараті «Philips 350» 3 використанням датчиків S-8 і S-12, а також на апараті «Toshiba Artida» 3 використанням датчиків S 4-6. Для обстеження був використаний B (2D) режим для визначення situs органів, положення і позиції серця, топографії магістральних судин, конкордантності передсердно-шлуночкового співвідношення, розміру порожнин серця, морфології клапанного і підклапанного апарату, наявності додаткових структур та іншого. За допомогою кольорового доплерівського дослідження визначали наявність патологічних шунтів, фрункцію клапанного апарату. За допомогою імпульсно-хвильового (PW) та постійнохвильового доплера (CW) досліджували градієнти тиску.

Обстеження всіх пацієнтів було проведено відповідно до локального протоколу ультразвукового дослідження 3 використанням стандартних позицій для обстеження серця: субкостальної, супрастернальної, парастернальної позиції по довгій і короткій осях, апікальної чотири- i п'ятикамерних позицій, а також «високої» парастернальної позиції, що є специфічною для візуалізації ВАП.

Зважаючи, що ВАП при ліво-правому скиданні крові належить до вад зі збагачення легеневого кровотоку, при ультразвуковому дослідженні значну увагу приділяли ознакам перевантаження малого кола кровообігу і всім визначеним раніше ознакам відкритої артеріальної протоки.

Для обробки матеріалу використовували дисперсійний аналіз, розраховували коефіцієнти достовірності. Після порівняння основної та контрольної груп були визначені фрактори, які мають певну значущість для діагностики уродженої вади серця у дітей. Були відібрані лише ті 3 них, які мають достовірні відмінності для названих вище груп $(p<0,05)$. Визначення значущості певного фрактора проводили за показником його сили впливу і показником інформативності.

Результати дослідження та їх обговорення. Вивчення та аналіз медико-соціальних чинників на першому етапі дослідження дозволили виділити найбільш значущі з них при розвитку відкритої артеріальної протоки. 3 усіх вивчених нами фракторів відібрано 19 статистично значущих, сила впливу яких була на рівні 1-7 \%. Найбільш позитивно значущим в цій групі виявився фрактор планування вагітності в медико-генетичному центрі або жіночій консультації з силою впливу 7 \%. Такі фрактори, як наявність УВС у родоводі та в матері мали сили впливу 5 і 4 \% відповідно. Значущим визначено фрактор природного вигодовування $з$ силою впливу $4 \%$.

Наступні з перерахованих фракторів мали силу впливу 2-1 \%. Це такі фрактори, як професійні шкідливості одного з батьків, наявність УВС у батька дитини, загроза переривання вагітності, проживання в екологічно забрудненому районі, вік матері на момент народження дитини більше 35 років, безпліддя, ожиріння матері, зв'язок членів родини $з$ ліквідацією аварії на ЧАЕС або проживанням на території зараження, аборти в анамнезі, тяжкий токсикоз першої половини вагітності, анемія і приймання лікарських препаратів під час вагітності та характер пологів.

Друга частина дослідження містить аналіз результатів обстеження пацієнтів за стандартною 
схемою, а саме скарги, огляд, рентгенографію органів грудної клітки, електрокардіографрію.

Найпоширенішими скаргами в основній групі $(78,0 \pm 2,8)$ \% були часті простудні захворювання, а також перенесені бронхіти і пневмонії, в той час, як у контрольній групі ці скарги відзначили тільки $(22,7 \pm 2,9) \%$ респондентів ( $<<0,001)$. Діти основної групи мали повільну прибавку маси тіла після народження, на що вказали $(53,2 \pm 3,4) \%$ батьків, тоді як у контрольній групі ці скарги спостерігали лише у $(7,2 \pm 1,8) \%$ сімей $(p<0,001)$. А в цілому на відставання у фрізичному і психомоторному розвитку в ранньому дитячому віці вказали $(65,6 \pm 3,2) \%$ і $(20,8 \pm 2,8) \%$ батьків дітей основної та контрольної груп відповідно ( $p<0,001)$.

Деякі пацієнти шкільного віку відзначали колючий біль в ділянці грудної клітки, який посилювався при диханні. За даними літератури, лише 4-6 \% такого болю припадає на серцеву патологію, поступаючись ідіопатичному, легеневому, психіатричному, м'язовому і гастроінтестинальному. Водночас серед серцевої патології, крім уроджених вад, больовий синдром можуть викликати різні види аритмій і підвищений або знижений артеріальний тиск [8].

Під час об'єктивного огляду дітей основної групи звертали увагу на ознаки відставання в розвитку, а також наявність діастолічного або систоло-діастолічного шуму при аускультації 3 максимальною гучністю над легеневою артерією $(90,8 \pm 2,0) \%(p<0,001)$ і класичний «машинний шум» (в основну групу не увійшли пацієнти 3 «німими» формами ВАП). Як в основній, так і в контрольній групі відзначалися зміни на ЕКГ. 3 огляду на те, що значна частина основної групи - це діти молодшого віку, якісне проведення дослідження становить технічні труднощі. Внаслідок цього, патологія на ЕКГ, що вивчалася, була зведена до такої, яка найбільш просто виявляється, а самі ознаки перевантаження камер серця і наявність порушення проведення у вигляді повної і неповної блокад правої ніжки пучка Гіса. У $(47,7 \pm 3,4)$ \% дітей основної групи було діагностовано ознаки перевантаження лівих камер серця і в $(11,9 \pm 2,2) \%$ - ознаки перевантаження правих камер серця ( $<<0,001)$. Наявність неповної блокади правої ніжки пучка Гіса було виявлено при ЕКГ у $(34,9 \pm 3,2) \%$ дітей основної групи і в $(17,9 \pm 2,7) \%$ дітей контрольної групи $(p<0,001)$. Аналізуючи отримані дані можна відзначити, що ознаки перевантаження лівих камер серця $€$ характерною і відомою діагностичною ознакою відкритої артеріальної протоки і наші дані лише це підтверджують. Щодо наступних двох ЕКГ даних, а саме ознак перевантаження правих камер серця і неповної блокади правої ніжки пучка Гіса, можна відзначити, що вони можуть враховуватися при дисреренціальній діагностиці як додаткові ознаки, оскільки мали, за нашими даними, сили впливу 4 і 3 \% відповідно.

Рентгенологічне обстеження органів грудної клітки, проведене в прямій проекції, аналізували за такими критеріями: стан та розмір серця i його камер відповідно до віку, а також стан легеневої структури (наявність або відсутність ознак гіперволемії малого кола кровообігу). Ознаки перевантаження правих камер серця, за даними рентгенографії, спостерігали у $(7,8 \pm 1,8) \%$ дітей основної групи і лише у $(1,0 \pm 0,7)$ \% дітей контрольної із силою впливу $3 \%(p<0,01)$, що також можна вважати однією із додаткових ознак ВАП.

При обстеженні пацієнта 3 передбачуваним діагнозом відкритої артеріальної протоки основними ультразвуковими критеріями були наявність фрункціонуючої протоки, її діаметр, напрямок шунта і гемодинамічна значущість. Критерієм діагнозу ВАП була візуалізація скидання при кольоровому доплерівському картируванні (КДК) у парастернальній позиції по короткій осі та у «високій» парастернальній та/або у супрастернальній позиціях. Додатковим дослідженням при наявності ВАП $є$ вимірювання градієнта при скиданні, вимір площі струменя, аналіз фрорми струменя і насиченості в режимі швидкісного доплера, вимір основи діаметра струменя в стовбурі легеневої артерії. Критеріями дилатації були дані підрахунку нормального значення масо-зростового показника в програмі Z-score. Найчастішими додатковими ознаками виявилися параметри, пов'язані з вимірами легеневої артерії у локусі, де вона безпосередньо з'єднується з ВАП.

Найчастішою ознакою виявилася дилатація лівої гілки легеневої артерії. Частота її виявлення в основній групі склала $(77,1 \pm 2,8) \%$, в той час як у контрольній групі в $(95,7 \pm 1,4) \%$ таку ознаку не спостерігали. Цей фракт може бути зумовлений анатомічною особливістю локалізації ВАП, бо найчастіше ділянкою її впадання є ліва гілка легеневої артерії. Вимірювання цього параметра було зроблено з парастернальної позиції по короткій осі у В-режимі. Сила впливу цього параметра виявилася найвищою і склала $54 \%$.

Також високу силу впливу (48 \%) мала і дилатація стовбура легеневої артерії, що відзначено в основній групі у $(78,0 \pm 2,8) \%$, а в контрольній лише у $(8,7 \pm 2,0) \%$ пацієнтів. Підвищення градієнта в стовбурі легеневої артерії найімовірніше зумовлено гіперволемією і за частотою та за значенням сили впливу полягало у наступному. Цей параметр вимірювали з парастернальної позиції по короткій осі в режимах швидкісного доплера. Враховували максимальний градієнт у точці максимальної інтенсивності доплерівського спектра. Нами було виявлено, що підвищення градієнта на легеневій артерії було відзначено у $(71,1 \pm 3,1) \%$ пацієнтів основної групи, в контрольній групі 
такий параметр спостерігали лише у $(7,2 \pm 1,8) \%$ дітей, які були обстежені. Його сила впливу дорівнює 42 \%. Також було проведено селективне вимірювання градієнта тиску на гілках легеневої артерії. Підвищення градієнта на правій гілці легеневої артерії було статистично недостовірним, а підвищення градієнта на лівій гілці легеневої артерії відзначено у $(48,2 \pm 3,4) \%$ і було достовірним із силою впливу $12 \%$.

Наступну підгрупу фракторів склали вимірювання лівих камер серця, які були проведені в основних двох позиціях: парастернальній по довгій осі й апікальній. Дослідження проводили в режимі реального часу - В-режимі та М-режимі. Силу впливу 36 \% з наявністю у $(67,0 \pm 3,2) \%$ пацієнтів основної групи і в $(8,7 \pm 2,0)$ \% пацієнтів контрольної групи мала дилатація лівого шлуночка 3 парастернальної позиції по довгій осі у В-режимі (рис. 1). Збільшення передньо-заднього розміру лівого передсердя з парастернальної позиції по довгій осі у В-режимі в основній групі спостерігали у $(72,5 \pm 3,0) \%$ пацієнтів, в контрольній - лише у $(19,3 \pm 2,7) \%$ із силою впливу $28 \%$. Необхідно зазначити, що цей параметр входить до переліку критеріїв гемодинамічної значущості ВАП у недоношених новонароджених як співвідношення лівого передсердя до кореня аорти [6]. Силу впливу 20 \% ці ж параметри мали при вимірюванні в М-режимі. Така різниця в даних найімовірніше зумовлена особливостями виміру в М-режимі та складністю виведення чіткого перпендикуляра у дітей раннього віку.

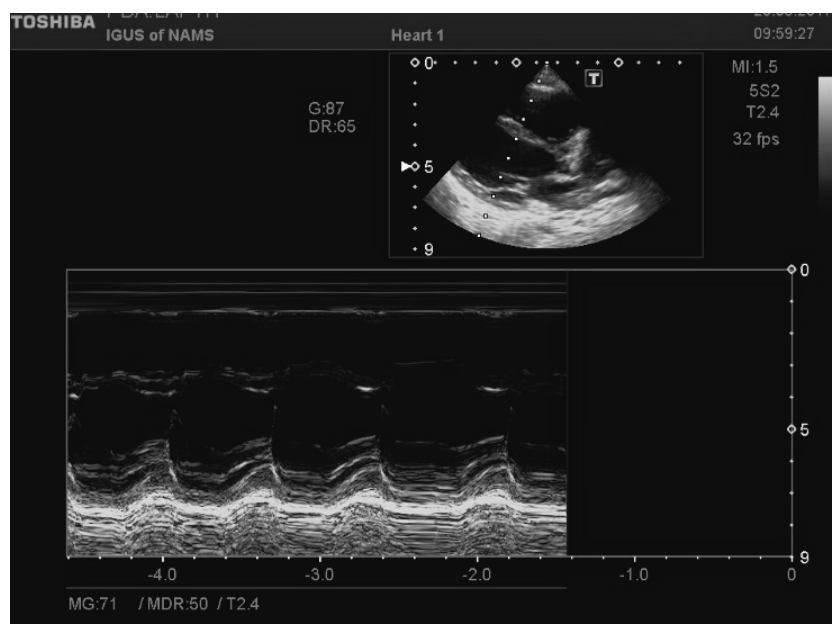

Puc. 1. Вимірювання лівого шлуночка 3 парастернальної позиції по довгій осі в В-режимі.

Дилатація лівого передсердя з апікальної чотирикамерної позиції у В-режимі була у $(56,0 \pm 3,4) \%$ основної групи та $(16,9 \pm 2,6) \%$ - у контрольній 3 силою впливу $16 \%$. Дилатація лівого шлуночка у В-режимі 3 апікальної позиції в основній групі зазначена у $(47,7 \pm 3,4) \%$ і в контрольній у $(15,5 \pm 2,5) \%$ із силою впливу $12 \%$ (рис. 2, 3). Отримані дані дозволили припустити більш ранні зміни передньо-заднього розміру і, відповідно, велику силу впливу змін із боку лівих камер серця при обстеженні пацієнта 3 парастернальної позиції по довгій осі.

Збільшення об'єму лівого передсердя $є$ предиктором значущого ліво-правого шунта, а також ознакою діастолічної дисфункції $[5,7]$. Об'єм лівого передсердя розраховували за трьома перпендикулярами в В-режимі із парастернальної позиції по довгій осі та 3 апікальної позиції. Збільшення об'єму лівого передсердя виявлено в основній групі у $(62,4 \pm 3,3) \%$ з силою впливу $20 \%$ (рис. 4).

Зміни з боку правих відділів серця були нечисленними, що зумовлено ранньою діагностикою пороку і відсутністю пацієнтів у вкрай тяжких станах в основній групі. Вимірювання правих камер серця були проведені з апікальної чотирикамерної позиції в В-режимі. Дилатацію правого передсердя було діагностовано частіше, ніж правого шлуночка.

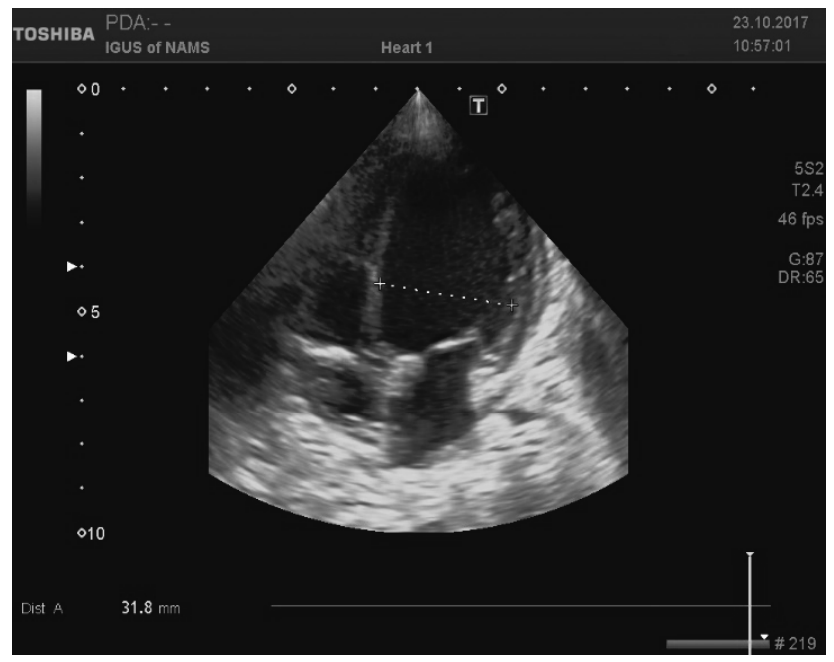

Puc. 2. Вимірювання лівого шлуночка з апікальної чотирикамерної позиції у В-режимі.

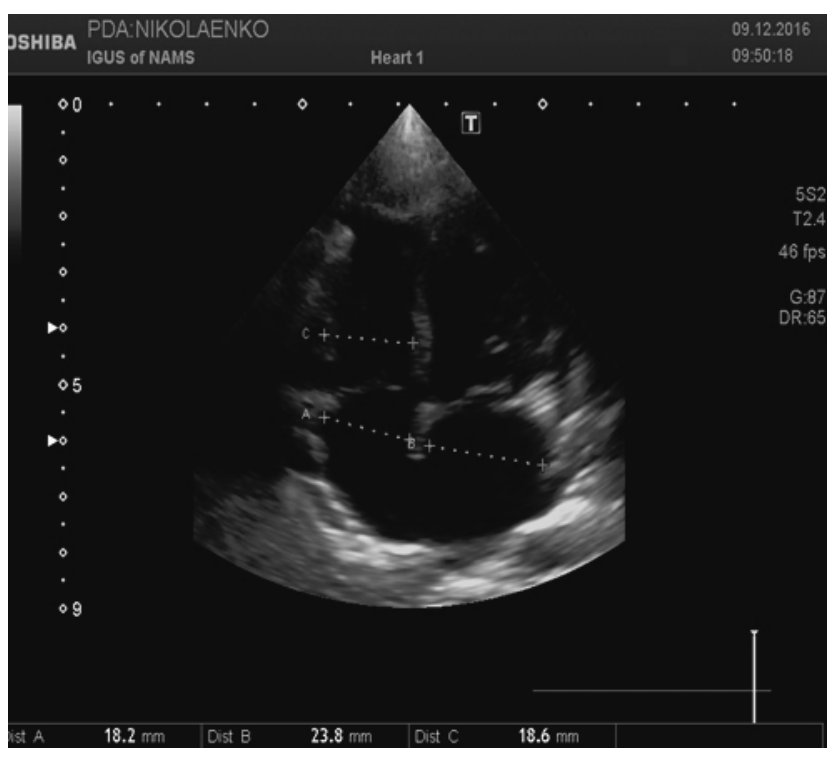

Puc. 3. Вимірювання лівого передсердя з апікальної чотирикамерної позиції. 


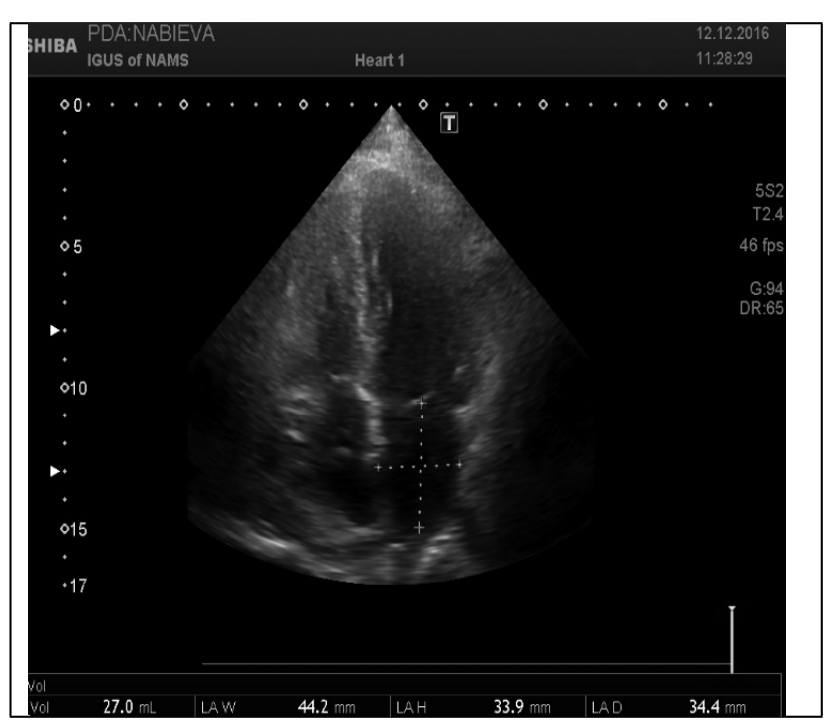

Puc. 4. Вимірювання об'єму лівого передсердя.

Так в основній групі її зафріксовано в $(19,3 \pm 0,8) \%$ пацієнтів, у той час як в контрольній групі такий відсоток був невеликий і в $(98,0 \pm 0,8) \%$ розміри правого передсердя були у межах вікової норми. Дилатацію правого шлуночка в основній групі було зафріксовано у $(14,2 \pm 2,4) \%$ пацієнтів, а в $(99,0 \pm 0,7) \%$ пацієнтів контрольної групи таких змін не виявлено. Ознаки дилатації правого передсердя і шлуночка мали силу впливу 8 та 6 \% відповідно.

При значному перевантаженні лівих камер серця може спостерігатися дисфункція діастоли лівого шлуночка. Основними критеріями визначення діастолічної функції $€$ вимір співвідношення піків раннього і пізнього діастолічного наповнення - E/A, а також співвідношення піків S/D на легеневих венах. Основними труднощами проведення даного вимірювання $€$ висока частота серцевих скорочень. 3 огляду на вік обстежуваних пацієнтів і прогнозовано низький відсоток диссункцій в діастолі, ці показники спостерігають рідко, в $(8,3 \pm 1,9) \%$ і $(7,3 \pm 1,8) \%$ пацієнтів основної групи з силою впливу 2 \% для кожної ознаки.

\section{Висновки}

1. Комплексне вивчення медико-соціальних чинників у розвитку відкритої артеріальної протоки у дітей дозволило відокремити статистично достовірні й найбільш значущі серед них, а саме планування вагітності в медико-генетичному центрі або жіночій консультації (сила впливу $7 \%$ ), що $є$ особливим для родин, у родоводі яких є випадки народження дітей із уродженими вадами серця.

2. Підтверджено значення природного вигодовування для фрізіологічного закриття відкритої артеріальної протоки у постнатальний період (сила впливу $4 \%$ ).

3. Доведено відставання у фізичному і психомоторному розвитку, часті простудні захворювання та повільну прибавку маси тіла у дітей 3 відкритою артеріальною протокою у ранньому дитячому віці $(65,6 \pm 3,2,78,0 \pm 2,8$ та $53,2 \pm 3,4) \%$ відповідно $(p<0,001))$.
4. Підтверджена діагностична значущість таких аускультативних даних, як наявність діастолічного або систоло-діастолічного шуму при аускультації з максимальною гучністю над легеневою артерією $(90,8 \pm 2,0) \%(p<0,001)$ та ознаки перевантаження камер серця, наявність порушення проведення у вигляді повної та неповної блокад правої ніжки пучка Гіса на ЕКГ. Такі фрактори, як перевантаження правих камер серця i неповна блокади правої ніжки пучка Гіса при ЕКГдослідженні можна враховувати при диференціальній діагностиці як додаткові ознаки (сила впливу 4 і 3 \% відповідно) разом із ознаками перевантаження правих камер серця за даними рентгенографрії (сила впливу $3 \%(p<0,01)$ ).

5. Проаналізовані ультразвукові критерії діагностики ВАП, серед яких найчастішими виявилися дилатація лівої гілки легеневої артерії $((77,1 \pm 2,8)$ \% дітей основної групи), дилатація стовбура легеневої артерії $((78,0 \pm 2,8) \%$ дітей основної групи), підвищення градієнта на легеневій артерії $((71,1 \pm 3,1) \%$ пацієнтів основної групи) та дилатація лівого шлуночка $((67,0 \pm 3,2) \%$ пацієнтів основної групи). Ці критерії мають значні рівні сили впливу і є основними діагностичними.

6. Досліджені додаткові ультразвукові критерії діагностики ВАП, якими виявилися збільшення передньо-заднього розміру лівого передсердя (у $(72,5 \pm 3,0) \%$ дітей основної групи, сила впливу 28 \%), збільшення об'єму лівого передсердя (у $(62,4 \pm 3,3) \%$ дітей основної групи, сила впливу $20 \%)$, підвищення градієнта на лівій гілці легеневої артерії (у $(48,2 \pm 3,4) \%$ дітей основної групи, сила впливу $12 \%)$, дилатація лівого передсердя (у $(56,0 \pm 3,4) \%$ дітей основної групи, сила впливу $16 \%)$, дилатація лівого шлуночка (у $(47,7 \pm 3,4) \%$ дітей основної групи, сила впливу $12 \%)$, а також ознаки дилатації правого передсердя і правого шлуночка $(19,3 \pm 0,8$ та $14,2 \pm 2,4 \%$, із силами впливу 8 та $6 \%$ відповідно).

7. Визначення додаткових діагностичних критеріїв відкритої артеріальної протоки у дітей дасть змогу вивчити гемодинамічну значущість цих критеріїв у комплексі для визначення подальшої тактики ведення пацієнтів із такими вадами серця та визначати для них спосіб хірургічного втручання.

8. Прогнозування ризику виникнення відкритої артеріальної протоки у дітей в комплексі з сучасними методиками ранньої діагностики та лікування цієї патології дозволить знизити державні витрати на медичне обслуговування таких дітей та підвищити якість медичного обслуговування.

Перспективи подальших досліджень. Отримані в результаті дослідження дані стануть складовою частиною алгоритму ведення пацієнтів із відкритою артеріальною протокою в амбулаторних умовах та в умовах стаціонару, а також для визначення способу та доступу до хірургічного втручання. 


\section{Список літератури}

1. Врожденные пороки сердца: структура, особенности течения гемодинамически значимых пороков [Электронный ресурс] / В. А. Квашевич, С. А. Лоскутова, Т. В. Белоусова, И. В. Андрюшина // Медицина и образование в Сибири. 2013. - № 4. - Режим доступа к журналу : http://ngmu.ru/cozo/mos/article/abauthors.php?id=1063.

2. Изучение фракторов, влияющих на фрормирование врождённыхпороков развития новорождённых/ Д. А. Маисеенко, М. Ю. Галактионова, О. А. Шурова [и др.] // Мать и Дитя в Кузбассе. - 2016. - № 1 (64). - С. 53-55.

3. Селютина М. Ю. Врожденные пороки развития как показатель экологического состояния окружающей среды [Электронный ресурс] / М. Ю. Селютина, В. И. Евдокимов, Г. А. Сидоров // Научные ведомости Белгородского государственного университета. Серия Медицина. Фармация. - 2014. - № 11 (182). - С. 173-177. - Режим доступа к журналу : http://dspace.bsu.edu.ru/handle/123456789/18587.

4. Социально-гигиенические и медико-биологические факторы риска развития врожденных пороков сердца у детей / Т. И. Нелунова, Т. Е. Бурцева, В. Г. Часнык, С. А. Евсеева // Якутский медицинский журнал. - 2018. - № 2. C. 116-119. - DOI 10.25789/YMJ.2018.62.37.

5. Echocardiographic measurement of left atrial volume: does the method matter? / C. Cimadevilla, B. Nadiaa, J. Dreyfusa [et al.] // Archives of Cardiovascular Disease. - 2015. - Vol. 108, No. 12. - P. 643-649. - DOI: dx.doi.org/10.1016/j. acvd.2015.07.001

6. Normal values of left atrial volume in pediatric age group using a validated allometric model / P. Bhatla, J. C. Nielsen, H. H. Ko, J. Doucette [et al.] // Circ. Cardiovasc. Imaging. - 2012. - Vol. 5, N6. - P. 791-796. - DOI: 10.1161/ CIRCIMAGING.112.974428.

7. Pediatric and adolescent chest pain: a cross sectional study / Mohammad Reza Khalilian, Abdolrahman Emami Moghadam, Mehdi Torabizadeh [et al.] // Int. J. Pediatr. - 2015. - Vol. 3, No. 1-2, No.14 - P. 435-440.

8. Transcatheter versus surgical closure of patent ductus arteriosus in pediatric patients: a systematic review with metaanalysis / M. E. Nady, D. E. Amrousy, N. Salah, A. Zoair // Journal of Pediatric Surgery. - 2017. - Vol. 3, No. 4. - P. 1-6. 9. Which criteria are more valuable in defining hemodynamic significance of patent ductus arteriosus in premature infants? Respiratory or echocardiographic? / i. O. Şahin, C. Yolcu, A. E. Şahin [et al.] // Med. Bull. Haseki. - 2017. - Vol. 55, No. 1. P. 32-36. - DOI: 10.4274/haseki.3278

\section{References}

1. Kvashevich, V.A., Loskutova, S.A., Belousova, T.V., \& Andryushina, I.V. (2013). Vrozhdennyye poroki serdtsa: struktura, osobennosti techeniya gemodinamicheskikh znachimykh porokov [Congenital heart defects: structure, features of the flow of hemodynamically significant defects]. Meditsina i obrazovaniye v Sibiri-Medicine and Education in Siberia, 4. Retrieved from: http://ngmu.ru/cozo/mos/article/abauthors.php?id=1063 [in Russian].

2. Mayseenko, D.A., Galaktionova, M.Yu., Shurova, O.A., Kapitonov, V.F., \& Polonskaya, O.V. (2016). Izucheniye faktorov, vliyayushchikh na formirovaniye vrozhdonnykh porokov razvitiya novorozhdonnykh [The study of factors affecting the formation of congenital malformations of newborns]. Mat i Ditya v Kuzbasse - Mother and Child in Kuzbass, 1 (64), 53-55 [in Russian].

3. Selyutina, M.Yu., Yevdokimov, V.I., \& Sidorov, G.A. (2014). Vrozhdennyye poroki razvitiya kak pokazatel ekologicheskogo sostoyaniya okruzhayushchey sredy [Congenital malformations as an indicator of the ecological state of the environment]. Nauchnyye vedomosti Belgorodskogo gosudarstvennogo universiteta. Seriya Meditsina. Farmatsiya - Scientific Gazette of Belgorod State University. Medicine series. Pharmacy, 11 (182), 26, 173-177 Retrieved from: http://dspace.bsu.edu.ru/ handle/123456789/18587 [in Russian].

4. Nelunova, T.I., Burtseva, T.E., Chasnyk, V.G., \& Evseeva, S.A. (2018). Sotsialno-gigiyenicheskiye i medikobiologicheskiye faktory riska razvitiya vrozhdennykh porokov serdtsa u detey [Socio-hygienic and biomedical risk factors for the development of congenital heart defects in children]. Yakutskiy meditsinskiy zhurnal - Yakutskyy Medical Journal, 2, 116-119 [in Russian].

5. Cimadevilla, C., Nadiaa, B., \& Dreyfusa, J. (2015). Echocardiographic measurement of left atrial volume: does the method matter? Archives of Cardiovascular Disease, 108 (12), 643-649.

6. Bhatla, P., Nielsen, J.C., Ko, H.H., \& Doucette, J. (2012). Normal values of left atrial volume in pediatric age group using a validated allometric model. Circ. Cardiovasc. Imaging, 5 (6), 791-796.

7. Mohammad reza Khalilian, Abdolrahman Emami moghadam, Mehdi Torabizadeh, Foroogh Khalilinejad, Sedigheh Moftakhar (2015). Pediatric and adolescent chest pain: a cross sectional study. Int. J. Pediatr, 3, 1-2 (14), 435-440.

8. Nady, M.E., Amrousy, D.E., Salah, N. \& Zoair A. (2017). Transcatheter versus surgical closure of patent ductus arteriosus in pediatric patients: a systematic review with meta-analysis. Journal of Pediatric Surgery, 3 (4), 1-6.

9. Şahin, I.O., Yolcu, C., \& Şahin, A.E. (2017). Which criteria are more valuable in defining hemodynamic significance of patent ductus arteriosus in premature infants? Respiratory or echocardiographic? Med. Bull. Haseki, 55 (1), 32-36.

\section{КОМПЛЕКСНЫЙ АНАЛИЗ ФАКТОРОВ И КЛИНИКО-ИНСТРУМЕНТАЛЬНЫХ ДАННЫХ ПРИ ОТКРЫТОМ АРТЕРИАЛЬНОМ ПРОТОКЕ У ДЕТЕЙ РАЗЛИЧНЫХ ВОЗРАСТНЫХ ГРУПП}

Д. А. Куликова ${ }^{1}$, Л. И. Чумак²

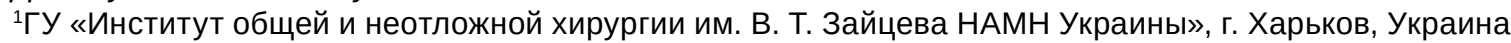

${ }^{2}$ Харьковский национальный университет имени В. Н. Каразина, г. Харьков, Украина

Цель: изучить и проанализировать медико-социальные фракторы и клинико-инструментальные данные при открытом артериальном протоке у детей различных возрастных групп. 
Материалы и методы. В исследовании приняли участие дети в возрасте до 18 лет, 80 \% из них дети до 3 лет. Все они проходили исследование в отделении кардиохирургии ГУ «Институт общей и неотложной хирургии им. В. Т. Зайцева НАМН Украины» в течение 2013-2017 гг. Основную группу составили пациенты с врожденным пороком сердца: открытый артериальный проток с проверенными данными комплексного обследования и данными УЗИ. Контрольная группа - пациенты без врожденных пороков сердца. Выполнен статистический анализ медико-социальных факторов, выявленных при анкетировании семей, данных объективного осмотра, клинико-инструментальных и данных ультразвукового исследования.

Результаты. Установлено, что среди медико-социальных фракторов наиболее положительно значимым является планирование беременности, а также жалобы на отставание в фризическом и психомоторном развитии, частые простудные заболевания и медленная прибавка массы тела у детей с открытым артериальным протоком в раннем детском возрасте. Среди косвенных признаков открытого артериального протока, по данным ультразвукового исследования, наиболее значимыми были дилатация левой ветви и ствола легочной артерии и повышение градиента давления на них. Дополнительными ультразвуковыми критериями для диагностики открытого артериального протока следует считать увеличение передне-заднего размера и объема левого предсердия, а также дилатацию левого предсердия и левого желудочка. Указанные критерии будут важными для определения гемодинамической значимости этого порока.

Выводы. Полученные данные позволяют определить значимость названных критериев в комплексе для выбора дальнейшей тактики ведения таких пациентов, а также станут неотъемлемой частью алгоритма ведения пациентов с открытым артериальным протоком.

КЛЮЧЕВЫЕ СЛОВА: врожденные пороки сердца; открытый артериальный проток; медикосоциальные факторы; дополнительные ультразвуковые признаки открытого артериального протока.

\section{COMPLEX ANALYSIS OF FACTORS AND CLINICAL-INSTRUMENTAL DATA IN CHILDREN OF DIFFERENT AGE GROUPS WITH PATENT DUCTUS ARTERIOSUS}

D. O. Kulikova ${ }^{1}$, L. I. Chumak ${ }^{2}$

${ }^{1} \mathrm{~V}$. Zaytsev Institute of General and Emergency Surgery, NAMS of Ukraine», Kharkiv, Ukraine

${ }^{2}$ V. Karazin Kharkiv National University, Kharkiv, Ukraine

Purpose: to study and analyze the medical-social factors and clinical-instrumental data in children of different age groups with patent ductus arteriosus (PDA).

Materials and Methods. The study involved children under the age of $18,80 \%$ - children under 3 years of age. All were examined at the Department of Cardiac Surgery of V. Zaitsev Institute of General and Emergency Surgery, NAMS of Ukraine, during 2013-2017. The first major group included patients with Congenital heart defect: patent ductus arteriosus with verified data from a comprehensive examination and ultrasound data. The other (control) group is patients without congenital heart disease.

The statistical analysis of medical and social factors, which were discovered during questioning of families, data of objective examination, clinical-instrumental and ultrasound examination, was performed.

Results. It is established that among the medical and social factors the most positive is the planning of pregnancy, as well as complaints of delay in physical and psychomotor development, frequent catarrhal diseases and failure to thrive in children with patent ductus arteriosus in early childhood. Among the indirect signs of the patent ductus arteriosus, according to ultrasound data, dilatation of the left branch and the trunk of the pulmonary artery and increased gradient of pressure on them were most significant. Additional ultrasound criteria for diagnosing an patent ductus arteriosus should be considered as an increase in the anterior-posterior size and volume of the left atrium, as well as the dilation of the left atrium and the left ventricle. These criteria will be significant in relation to the hemodynamic significance of this developmental defect.

Conclusions. The data obtained allow to determine the significance of the mentioned criteria in the complex for the choice of further tactics for managing of such patients, and will also become an integral part of the algorithm for managing patients with a patent ductus arteriosus.

KEY WORDS: congenital heart disease; patent ductus arteriosus; medical and social factors; indirect ultrasound signs of patent ductus arteriosus.

Рукопис надійшов до редакції 30.10 .2018 p.

\section{Відомості про авторів:}

Кулікова Дар'я Олександрівна - лікар-педіатр відділення кардіохірургії дУ «Інститут загальної та невідкладної хірургії ім. В. Т. Зайцева НАМН України»; тел.: +38(063) 628-73-45.

Чумак Любов Ігорівна - кандидат медичних наук, доцент, доцент кафредри загальної та клінічної патології Харківського національного університету імені В. Н. Каразіна; тел.: +38(067) 258-16-13. 